\title{
Encounters with uncertainty and complexity: Reflecting on infection prevention and control nursing in Aotearoa during the COVID-19 pandemic
}

\author{
Sarah Berger ${ }^{1}$, PhD, MBA, RN, Nursing Director \\ ${ }^{1}$ Canterbury DHB, Aotearoa New Zealand \\ Corresponding Author: sarah.berger@cdhb.health.nz
}

\begin{abstract}
Citation:
Berger, S. (2021). Encounters with uncertainty and complexity: Reflecting on infection prevention and control nursing in Aotearoa during the COVID-19 pandemic. Nursing Praxis in Aotearoa New Zealand, 37(3), 15-19.

https://doi.org.10.36951/27034542.2021.027
\end{abstract}

\begin{abstract}
The disruptiveness of the COVID-19 pandemic created the need for rapid responses in health systems already under pressure and challenged nursing in Aotearoa New Zealand with levels of uncertainty and complexity not previously encountered. For the small number of specialists in the field of infection prevention and control (IPC) nursing nationally, this meant having to adapt to new ways of working and collaborating in situations where the pace of change was extraordinary. This short commentary describes the author's experiences working as an infection prevention and control nurse leader and is underpinned by complex adaptive systems thinking and the concept of collective competence as theoretical frameworks through which to conceptualise and account for the COVID-19 response in the Canterbury region.
\end{abstract}

Keywords: COVID-19; infection prevention and control; nursing

\section{Introduction}

The COVID-19 (SARS-CoV-2 virus) pandemic has required rapid adaptation across health systems. Traditional health sector solutions to changes in the external environment are often driven top-down, though when faced with uncertainty and unpredictable situations, collaboration and shared responsibility may be more effective (Figueria et al., 2019; Hammond, 2000). An approach such as complex adaptive systems thinking, which has risen out of the study of biological and social systems in the field of complexity science (Senge, 2006; Waldrop, 1992), offers organisational leaders in health care a useful model to understand complex health systems, including how groups self-organise, learn, adapt and evolve in dynamically changing environments such as the COVID-19 pandemic response (Ratnapalan \& Lang, 2020; Rusoja et al., 2018). Furthermore, the cognitive and collaborative complexity of decisionmaking that must be negotiated by healthcare teams operating in the COVID-19 response has been complicated by the number and diversity of actors involved and by the potentially diverging values and objectives of these actors. This means even the process of agreeing on the exact nature of problems to be tackled is made more difficult, let alone finding agreement on broadly acceptable long-term solutions (Brown et al., 2010). Boreham (2004) defined three key characteristics of teams that effectively navigate these types of challenges: (a) collective sense-making of events; (b) making use of the knowledge base of the collective as a whole; and (c) a sense of interdependency. Boreham termed this collective competence. These two frameworks have supported and informed the author's understanding of the COVID-19 response in the Canterbury region.

\section{Infection and prevention control response}

As news of an emerging respiratory virus pandemic hit the headlines in early 2020 (McNeil, 2020), there was a noticeable increase in phone and email enquiries as anxious clinical staff sought infection and prevention control (IPC) advice. An interdisciplinary team from a range of health professions, joined forces to collectively support the IPC response to the pandemic. The integrated health system model in the Canterbury region has been previously described (Timmins \& Ham, 2013) and 
this model enabled the power of these existing networks to be promptly harnessed. At first, this coming together was unstructured and informal. Available colleagues met together first thing each morning and worked through questions of the day flooding in from clinicians via different pathways as best we could. Later this evolved into a formal Technical Advisory Group.

There was significant depth of experience and knowledge available from subject matter experts across the Canterbury Health System (including Canterbury Health Laboratories, Community and Public Health, Canterbury Primary Response Group, Department of Infectious Diseases, IPC Service) that provided strategic and operational input on infection prevention and control to health providers and other agencies across the region (Table 1). Strategic objectives focused on: a) monitoring overseas developments and advising on implications for the Canterbury region; b) ensuring IPC policy and practice remained fit for purpose and responsive to changes in epidemiology; and c) providing balanced, timely and evidence-based decisions on complex, farreaching, technical matters. However, achieving these objectives was no easy task. Interdisciplinary synergies and specialist knowledge were central to progress but as with other district health boards, we were dealing with a new threat and limited knowledge on how to best mitigate risks created by the SARS-CoV-2 virus.

The key challenge to be navigated was the difficulty posed by decision-making under uncertainty and dealing with the characteristic messiness arising from intrinsic cognitive and collaborative complexities in the situation (Berger et al., 2019; Lingard, 2012; Kahneman et al., 1982). For example, progress towards decisions was non-linear because as we collectively sought to make sense of the rapidly evolving international pandemic crisis and provide sound advice, we encountered obstacles such as conflicting opinions, knowledge deficits, physical and cognitive fatigue, and the general burden of responsibility. This led to back-tracking, redirecting and reframing of problems (Blumenthal-Barby \& Krieger, 2015; Ghosh, 2004). On the other hand, group performance benefited from the sense of interdependency and being in this together. We relied on each other's expertise and understood that decisions made by consensus were stronger and safer. Being able to tap into the shared knowledge base of the team as a whole, enabled problems to be conceptualised in novel ways and open interactions including positive and negative feedback prompted necessary modifications in thinking to ultimately enable satisfactory collaborative decisions (Boreham, 2004; Curşeu \& Schruijer, 2012; Lamb et al., 2011).

Looking back over the COVID-19 response to date, the most significant occurrence from an IPC nursing perspective has been a paradigm shift in relation to respiratory virus transmission. In the traditional IPC view, the mode of droplet transmission is where infectious droplets greater than $5 \mu \mathrm{m}$ in diameter fall rapidly to the ground under gravity, and therefore are transmitted only over a limited distance $(\leq 1 \mathrm{~m})$. Another mode of airborne transmission is where infectious droplet nuclei, defined as $5 \mu \mathrm{m}$ or smaller in size, are carried on air currents particularly indoors (Centers for Disease Control and Prevention, 2016). Early in the pandemic, published evidence and expert guidance indicated that transmission of SARSCoV-2 virus was predominantly via the droplet route and that airborne transmission had not been reported (Ong et al., 2020; World Health Organisation, 2020). However, transmission investigations undertaken locally ultimately led to a rethinking of respiratory virus transmission, at least as far as it related to SARS-CoV-2 (Eichler et al., 2021).

A turning point in the thinking about transmission occurred during the investigation of two cases of guest-to-nurse transmission events linked to a large cohort of mariners with COVID-19 in a managed isolation and quarantine facility. At that time, we were working with the droplet transmission model, where the recommended mask was a surgical mask (vaccination was not yet available). This investigation established that there were no breeches of personal protective equipment and evidence drove consideration to other possible explanations (Lancet Respiratory Medicine, 2020). In this instance, transmission was ultimately identified as being due to poor ventilation and virus-laden aerosol particles, carried from rooms into corridors in which the nursing staff were working when doors were opened and closed. This realisation also triggered reexamination of a guest-to-guest transmission event that had occurred earlier in another Canterbury managed isolation and quarantine facility (initially linked to possible fomite transmission through the 
Table 1: Canterbury region's COVID-19 Integrated Infection Prevention and Control Response

\begin{tabular}{|c|c|c|}
\hline & Objectives & Examples of IPC contributions to COVID-19 Response \\
\hline \multirow[t]{3}{*}{$\begin{array}{l}\text { Strategic } \\
\text { Input }\end{array}$} & \multirow{3}{*}{$\begin{array}{l}\text { Monitoring overseas } \\
\text { developments and } \\
\text { advising on } \\
\text { implications for the } \\
\text { Canterbury region } \\
\text { Ensuring IPC policy } \\
\text { and practice } \\
\text { remains fit for } \\
\text { purpose and } \\
\text { responsive to } \\
\text { changes in } \\
\text { epidemiology } \\
\text { Providing balanced, } \\
\text { timely and evidence- } \\
\text { based decisions on } \\
\text { complex, far- } \\
\text { reaching, technical } \\
\text { aspects of COVID-19 } \\
\text { response }\end{array}$} & $\begin{array}{l}\text { Clinical Governance } \\
\text { - } \quad \text { COVID-19 Technical Advisory Group membership } \\
\text { Leadership in Policy and Procedure } \\
\text { - } \quad \text { Canterbury DHB IPC SOP1 “Guidance for Isolation and Quarantine Hotels” } \\
\text { adopted as foundation for MBIE's national IPC SOP } \\
\text { - } \quad \text { IPC Specialist input into national MOH ventilation and air cleaning project } \\
\text { (and ventilation protocols in MIQF) } \\
\text { - } \quad \text { CDHB change to N95 mask use for health staff (following staff infection at } \\
\quad \text { Sudima MIQF) adopted into MBIE's national IPC SOP }\end{array}$ \\
\hline & & $\begin{array}{cl}\text { Critical Incident Investigations } \\
\text { - } & \text { Case investigation Crowne Plaza MIQF guest-to-guest transmission } \\
\text { - } & \text { Case investigation Sudima MIQF guest-to-staff transmission } \\
\text { - } & \text { Sports teams breeches of exemption conditions in MIQF } \\
- & \text { Breeches of protocols by returnees in MIQF }\end{array}$ \\
\hline & & $\begin{array}{cc}\text { Service on National Committees } \\
- & \text { HQSC Strategic IPC Advisory Group (SIPCAG) } \\
- & \text { MOH National IPC Expert Group (NIPCEG) } \\
- & \text { MOH COVID-19 Clinical Governance Meeting } \\
- & \text { MOH National IPC Leads } \\
- & \text { MOH National MIQF IPC Leads }\end{array}$ \\
\hline \multirow[t]{5}{*}{$\begin{array}{l}\text { Operational } \\
\text { Input }\end{array}$} & \multirow[b]{2}{*}{$\begin{array}{l}\text { support surveillance } \\
\text { and testing }\end{array}$} & $\begin{array}{l}\text { Surveillance } \\
\quad-\quad \text { Monitoring incidence and prevalence of cases in the electronic } \\
\quad \text { surveillance system (ICNet) } \\
\end{array}$ \\
\hline & & $\begin{array}{c}\text { Management of Confirmed Cases and Close Contacts } \\
-\quad \text { Supporting Public Health as required with transmission investigations and } \\
\text { - } \\
\text { contact tracing } \\
\text { Overseeing IPC protocols for positive case transfers to quarantine } \\
\end{array}$ \\
\hline & Collaborating with & $\begin{array}{cl}\text { Canterbury Managed Isolation and Quarantine Facilities } \\
\text { - } & \text { Assessing hotel suitability to function as MIQF } \\
\text { - } & \text { Advising on room configuration for quarantine/isolation in MIQF } \\
\text { - } & \text { Establishing IPC policy and procedure for MIQF } \\
\text { - } & \text { Partnering with Canterbury Regional Isolation and Quarantine (C-RIQ) } \\
& \text { staff on IPC requirements in MIQF } \\
\text { - } & \text { Conducting observational walk-throughs and assessments of IPC SOPs in } \\
& \text { MIQF } \\
\text { - } & \text { On-going training for all workforce groups }\end{array}$ \\
\hline & \multirow[t]{2}{*}{$\begin{array}{l}\text { 4. Identifying } \\
\text { opportunities to } \\
\text { improve safety, } \\
\text { health and welfare } \\
\text { of staff }\end{array}$} & $\begin{array}{cl}\text { Special Projects } \\
- & \text { Providing IPC expert input on appropriate protocols for } \\
\text { special groups with exemptions i.e. international sports teams } \\
\text { - } & \text { Reviewing pathways and planned renovations at Christchurch Airport } \\
\text { (Red pathway for returnees in both domestic \& international arrivals as } \\
\text { travel bubbles introduced with neighbouring countries) }\end{array}$ \\
\hline & & $\begin{array}{cl}\text { Training and Education (across Canterbury Health System and beyond) } \\
\text { - } & \text { Staff training (all workforce groups and across sectors) } \\
- & \text { N95 mask use/PPE refresher training/nasopharyngeal swabbing } \\
& \text { technique } \\
\text { - } & \text { Coaching/guidance for staff on IPC SOPs and IPC protocols }\end{array}$ \\
\hline
\end{tabular}

use of communal rubbish bins). Closed-circuit television footage was reviewed, and it was noted that during routine day 12 testing only a 50 -second window of time elapsed between one door closing and the next door opening for the cases. It was hypothesised that suspended aerosol particles were a more probable mode of transmission (Eichler et al., 2021). Ultimately, SARS-CoV-2 transmission events have helped us understand that virus-laden infectious respiratory particles exist on a continuum from large droplets to droplet nuclei and aerosols (Tang et al., 2021). Practice has consequently changed and includes the use of appropriate respiratory protection (fit-tested N95 masks) and transmission-based precautions for airborne diseases (Lancet Respiratory Medicine, 2020; Tang et al., 2021). 


\section{Future Perspectives}

The COVID-19 pandemic continues to pose significant challenges to health systems and wider social systems that were already under strain. Yet a continued response to this crisis is required. Understanding the Canterbury response to COVID-19 has been supported by complex adaptive systems thinking and the concept of collective competence. It has highlighted how an effective response to health service challenges is facilitated by leveraging off existing networks, promoting multi-stakeholder engagement and sharing knowledge across disciplines with a collaborative approach.

\section{References}

Berger, S., Whelan, B., Mahler, C., Szecsenyi, J., \& Krug, K. (2019). Encountering complexity in collaborative learning activities: An exploratory case study with undergraduate health professionals. Journal of Interprofessional Care, 33, 490-496. https://doi.org/10.1080/13561820.2018.1562423

Blumenthal-Barby, J.S., \& Krieger, H. (2015). Cognitive biases and heuristics in medical decision making: $A$ critical review using a systematic search strategy. Medical Decision Making, 35, 539-557. https://doi.org/10.1177/0272989X14547740

Boreham, N. (2004). A theory of collective competence: Challenging the neo-liberal individualization of performance at work. British Journal of Educational Studies, 52(1), 5-17. https://www.jstor.org/stable/1555934

Brown, V., Harris, J., \& Russell, J.Y. (2010). Tackling wicked problems through the transdisciplinary imagination. Earthscan.

Centers for Disease Control and Prevention. (2016, January 7). Transmission-Based Precautions. https://www.cdc.gov/infectioncontrol/basics/transm ission-based-precautions.html

Curşeu, P., \& Schruijer, S. (2012). Normative interventions, emergent cognition and decision rationality in ad hoc and established groups. Management Decision, 50, 1062-1075. http:/doi.org/10.1108/00251741211238337

Eichler, N., Thornley, C., Swadi, T., Devine, T., McElnay, C., Sherwood, J., Brunton, C., Williamson, F., Freeman, J., Berger, S., Ren, X., Storey, M., de Ligt, J., \& Geoghegan, J.L. (2021). Transmission of severe acute respiratory syndrome Coronavirus 2 during border quarantine and air travel, New Zealand (Aotearoa). Emerging Infectious Diseases, 27(5), 1274-1278. https://doi: 10.3201/eid2705.210514

Figueroa, C. A., Harrison, R., Chauhan, A., \& Meyer, L. (2019). Priorities and challenges for health leadership and workforce management globally: A rapid review.
BMC Health Services Research, 19(1), 239. https://doi: 10.1186/s12913-019-4080-7.

Ghosh, A.K. (2004). On the challenges of using evidencebased information: The role of clinical uncertainty. The Journal of Laboratory and Clinical Medicine, 144(2), 6064. https://doi.org/10.1016/i.lab.2004.05.013

Hammond, K. (2000). Human judgment and social policy: Irreducible uncertainty, inevitable error, unavoidable justice. Oxford University Press.

Kahneman, D., Slovic, P., \& Tversky, A. (1982). Judgment under uncertainty: Heuristics and biases. Cambridge University Press.

Lamb, B.W., Brown, K.F., Nagpal, K., Vincent, C., Green, J.S., \& Sevdalis, N. (2011). Quality of care management decisions by multidisciplinary cancer teams: A systematic review. Annals of Surgical Oncology, 18, 2116-2125. http://doi.org/10.1245/s10434-0111675-6

The Lancet Respiratory Medicine. (2020). COVID-19 transmission-up in the air. [Editorial]. The Lancet Respiratory Medicine. 8(12), 1159. https://doi.org/10.1016/S2213-2600(20)30514-2

Lingard, L. (2012). Rethinking competence in the context of teamwork. In B. Hodges \& L. Lingard (Eds.), The question of competence: Medical education in the 21st century (pp. 42-69). Cornwell University Press. https://doi.org/10.7591/9780801465802-006

McNeil, D.G. Jr. (2020, February 2). Wuhan coronavirus looks increasingly like a pandemic, experts say. The New York Times. https://www.nytimes.com/2020/02/02/health/coro navirus-pandemic-china.html

Ong, S.W., Tan, Y.K., Chia, P.Y., Lee, T.H., Ng, O.T., Wong, M.S., \& Marimuthu, K. (2020). Air, surface environmental, and personal protective equipment contamination by severe acute respiratory syndrome coronavirus 2 (SARS-CoV-2) from a symptomatic patient. Journal of the American Medical Association. 323(16), 1610-1612. https://doi: 10.1001/jama.2020.3227.

Ratnapalan, S., \& Lang, D. (2020). Health care organizations as complex adaptive systems. The Health Care Manager, 39(1), 18-23. https://doi: 10.1097/HCM.0000000000000284.

Rusoja, E., Haynie, D., Sievers, J., Mustafee, N., Nelson, F., Reynolds, M., Sarriot, E., Swanson, R.C., \& Williams, B. (2018). Thinking about complexity in health: A systematic review of the key systems thinking and complexity ideas in health. Journal of Evaluation in Clinical Practice, 24, 600-606. https://doi: 10.1111/jep.12856.

Senge, P. (2006). The fifth discipline. The art and practice of the learning organization ( $2^{\text {nd }}$ ed.). Cornerstone.

Tang, J.W., Bahnfleth, W.P., Bluyssen, P.M., Buonanno, G., Jimenez, J.L., Kurnitski, J., Li, Y., Miller, S., Sekhar, C., Morawska, L., Marr, L.C., Melikov, A.K., Nazaroff, W.W., Nielsen, P.V., Tellier, R., Wargocki, P., \& Dancer, S.J. (2021). Dismantling myths on the airborne transmission of severe acute respiratory syndrome coronavirus-2 (SARS-CoV-2). Journal of Hospital 
Infection. 110, 89-96.

https://doi:10.1016/j.jhin.2020.12.022.

Timmins, N., \& Ham, C. (2013). The quest for integrated health and social care: A case study in Canterbury, New Zealand. The King's Fund.

Waldrop, M.M. (2019). Complexity: The emerging science at the edge of order and chaos. Open Road Media.
World Health Organization (2020, March 29). Modes of transmission of virus causing COVID-19: Implications for IPC precaution recommendations: Scientific brief. https://www.who.int/news-

room/commentaries/detail/modes-of-transmissionof-virus-causing-covid-19-implications-for-ipcprecaution-recommendations.

Funding: None

Conflicts of interest: None 